\title{
The Dynamics of Employee Voice: Evidence from Nigeria
}

\author{
Christine A. Nwuche (Ph.D) \\ Joseph E.O. Oshi (Ph.D) \\ Department of Management \\ Faculty of Management Sciences \\ University of Port Harcourt \\ Nigeria
}

\begin{abstract}
Employee voice and its presumed relevance in achieving improved organizational performance has become a recurring rhetoric in the employment relationship. This study explored the existence and functioning of employee voice schemes in organisations in South-South Nigeria. Survey data from 307 respondents from across five economic sectors were used. The data were analyzed using mainly descriptive statistics and the two hypotheses were tested using Spearman Rank order correlation coefficient. Results indicated the existence of a variety of employee voice schemes; that managers support the schemes and there was employees perception of say in how work is organized. However, based on the results, the study concludes that managers seem to commit to voice schemes that do not diminish their managerial prerogative. It also concluded that the meaning of "say" for both managers and employees appears to lie closer to a lower order voice category, wherein there is mere exchange of information rather than real involvement of employees in the making of workplace decisions. We recommend that considering the acclaimed relevance of employee voice, with respect to organisational performance, employers should wholeheartedly embrace employee voice systems and consciously encourage active involvement of employees, particularly those competent, knowledgeable and interested, in making decisions at work.
\end{abstract}

Keywords: Employee voice, Direct voice, Indirect representative voice, Dual voice, South-South Nigeria.

\section{Introduction}

Employee voice $(\mathrm{EV})$ is one of the evolving issues in human resource management. It refers to a rather nebulous phrase subject to wide-ranging usage. Early usage was rooted in the overly skewed balance of power in favour of the employer and the related establishment of trade unions. Trade unions served to provide workers voice to influence the terms and conditions in the employment relationship. That is, employee voice was initially seen in the context of industrial democracy which was touted to enable workers have some influence in unionized work settings (Marchington, 2010). Voice was perceived as key to achieving harmonious and effective employment relationship guaranteeing employee right and wherein trust, fairness and respect prevail (Ackers, Marchington, Dundon \&Wilkinson, 2006; Johnstone \&Ackers 2015). In non-union settings, voice has been located in joint consultative committees and work councils (Dundon, Wilkinson, Marchington \& Ackers 2004). Industrial democracy, joint consultation and work councils together come under the umbrella of indirect collective voice which for long occupied a central space in industrial relations.

More recently, analysis has been extended to explore direct models of voice. These models are premised largely on the tenets of employee involvement and participation (EIP) which itself is rooted in the notion of economic efficiency, achievable via employee motivation and commitment (Marchington \& Wilkinson 2009; Marchington, 2010; Johnstone \& Ackers, 2015). The agenda of direct voice differ markedly from those of industrial democracy. Unlike the latter, it is management-initiated and tends to be individualist, stressing direct communication with employees rather than through their unions or representatives.

A number of reasons have been advanced for the increased interest indirect voice in many OECD countries. Among these include the decline in trade union power which puts pressure on the effectiveness of indirect collective voice hence projecting direct forms of voice as the means to provide workers new opportunities for influence in the workplace (Marchington, 2010), even if it is at the peripheries of managerial decision making (Ramsay, Scholarios \&Harley, 2000). From the perspective of employers, many appear to show interest in direct voice because it is perceived as key to employee involvement, which is associated with high performance. (Marchington \& Kynighou, 2012; Johnstone \& Ackers, 2015). 
While overall, the balance appears to have shifted towards more direct voice forms, research evidence suggest that indirect voice has not been jettisoned. For instance, Bryson (2004), opines that voice systems are most effective, when direct and indirect voice forms exist in combination. Also, Georgiadis (2006) concludes that a combination of both forms relate strongly with employee commitment whilst Torre (2018) observed that collective voice relate with productivity. Howbeit, Johnstone \& Ackers (2015) take the view that only few British employers consider collective voice critical to strategy implementation.

The foregoing are views arising from research in developed economics. Since as Marchington (2010) points out, voice is not likely to operate similarly in different climes, and employers themselves are able to choose whether or not to adopt voice systems, the concern of this paper is to explore the voice scenario in organizations in Nigeria. The questions are: (i) What voice systems exist? (ii) To what extent are managers responsive to employee voice? (iii) Among employers, is there a preference for either direct or indirect voice or are the two used in combination? (iv) what are employees perceptions in relation to voice?(v) Are a combination of direct and indirect voice common place? We are not aware of studies in Nigeria that have specifically probed these issues, although some studies have examined the relationship between employee voice and variables such as organisational performance (Emmanuel, Yusuf Okoro, Francis \& Isaac, 2017) and productivity (Kitur \& Rop (2016). This study seeks to fill the gap. Our interest is to ascertain the types, combinations and strength of employee voice in organisations in Nigeria; the opportunities provided workers and the extent of their responsiveness to the phenomenon.

\section{Literature Review}

From a historical perspective employee voice (EV) is a socio-political concept often referred to as industrial democracy. In its ideal form, industrial democracy connotes workers control of industry. Its focus is to change the existing balance of power in industry and the creation of a system wherein workers determine the purpose, nature and methods of production (Salamon, 1992). Of course, it is doubtful that this model of organisation governance and management would be feasible.

More subtle conceptualization of industrial democracy is rooted in collective organisation and touts practices such as employee representation in management committees and at board levels which are intended to increase employee rights to participate in decision-making (Hollingshead \&Leat, 1995). This conceptualization also appears to concern breaking the shackles placed on employees by those with power in the workplace (Clegg, Kornberger \& Pitsis, 2011).Employees thus find the impetus to express their discontent, complaints or grievances and indeed, influence the power of management (Armstrong, 2009; Marchington \& Wilkinson 2009).

Other usages of EV tend to capture the evolutionary development in the authority relationships within organisations. In this respect, EV is seen as enabling employees to influence the actions of management (Millward, Stevens, Smart \& Hawes, 1992) and as referring to processes and structures which have the potential to empower employees both directly and indirectly to contribute to organisational decision making (Boxall \& Purcell, 2003). For McCabe and Lewin (1992), Armstrong (2009) and Marchington (2010), EV refers to practices designed to enable employees have some 'say' in their respective organisations. While Armstrong (2009) appears to perceive 'say' as a two-way dialogue between workers and management, Gospel and Palmer (1993) had suggested a 'say' continuum which ranges from unilateral determination by management with no employees influence, through individual bargaining, joint consultation and collective bargaining, to unilateral employee decision making. Similarly, Boxall and Purcell (2003) identify different gradations of voice. Theirs begins with little voice, wherein information is simply provided employees; through giving employees opportunity to make suggestions; being consulted during decision making and implementation; to having the right to delay a decision, veto management decision or outright co-determination of decision.

Marchington (2010) distinguishes between indirect and direct voice. Indirect voice includes union instigated forms of participation and non-union models such as joint consultative committees and work councils whilst direct voice broadly includes (i) task-based participation (ii) upward problem solving and (iii) complaints about fair treatment. We discuss the different voice forms below.

\section{Direct Voice}

(i) Task-based participation: A direct form of voice expected to add value by providing opportunities for employees to contribute to managerial decision making. Voice mechanisms here include team working, self-managed teams and autonomous work groups. Task-based participation is a high commitment model in which work-group members, particularly in self-managed teams, directly organize their work. With task-based participation, employees do more than simply respond to management instructions (Appelbaum, Bailey, Berg \& Kallenberg, 2000). 
Managers maybe attracted to this form of voice because of the expectation that it would lead to improvements in quality and productivity thus adding value to the organisation. Besides, evidence suggest that task-based participation results in more satisfying jobs for workers although it is also often associated with greater work intensity (Wilkinson, Godfrey \& Marchington, 1997).

(ii) Upward problem-solving: Includes a range of voice schemes designed to tap into employee knowledge and opinion either through individual suggestions or through small groups brought together specifically to resolve problems or generate new ideas (Marchington, 1995; Marchington, 2010). To this extent, they encourage greater level of voice than downward communication of information from the top to the bottom of the hierarchy. The objectives of upward problem-solving schemes, among others, are to increase the stock of ideas, encourage cooperation and legitimize change in the organisation (Marchington, 1995). Although these schemes are not integral to the regular work process (Batt, 2004), they are in tandem with the high commitment model since they appear to recognize employees as a major source of competitive advantage. Upward problem solving schemes include suggestion schemes, problem-solving groups/quality circles etc (Marchington, 2010). To this, Armstrong (2009) adds among others, attitude surveys and consultative committees.

(a) Suggestion schemes - These are bottom-up communication procedures which encourage employees to make suggestions concerning how practices and processes could be made more effective and efficient (Torrington, Hall \& Taylor, 2008). The rationale for suggestion schemes is that employees on the front-line interact more closely with equipment and customers on day-to-day basis and, therefore, have more operational details than higher level managers. It is suggested that organisations need to give tangible recognition/reward for employees suggestions that have benefitted the organisation, particularly those outside their work domain (Armstrong, 2009; Marchington 2010).Marchington and Wilkinson (2005) draw attention to the bad feelings that may result if workers feel that they are under-rewarded for their ideas that are of use to the organisation. However, there is also the danger of an instrumental approach to work amongst workers which paying for suggestions may encourage.

(b) Problem solving groups - these are small groups of workers brought together on a regular basis to analyse and develop solutions to quality and other work-related problems (Marchington, 2010) or develop ideas to improve productivity and for organisational product/service improvement generally. Quality circles, (QCs), a model of problemsolving groups, may consist of organisational members from same functional unit or, membership may be crossfunctional with focus on interdepartmental issues. Torrington et al. (2008) note that QCs do not serve only as a source of useful ideas for improving systems and saving costs but also do give people opportunity to contribute their thoughts and ideas, a salient evidence of voice. However, there is the view that managers lack of interest or work pressure may result to a situation wherein ideas generated by problem-solving groups may never be given adequate attention or even implemented (Paauwe \& Boselie, 2005).

(c) Attitude surveys- These are regular surveys of employees opinions to convey an honest picture of their morale and commitment to management (Torrington et al 2008). Information from surveys also serve to highlight employees preferences, potential problem areas, cause of particular problem and to compare levels of job satisfaction, morale and commitment of employees (Armstrong, 2009). Torrington et al(2008) emphasize that the challenge associated with attitude surveys arise when employees contributions are ignored or when surveys reveal serious problems which management fail to properly address. It is notable that many employers use surveys merely to give the impressions that they are committed to employee views (IRS, 2005b in Torrington et al 2008).

Generally, upward problem solving, as a form of direct voice, is associated with considerable tensions. As Marchington (2010) remarks, tensions arise because the techniques here operate at the interface between management and nonmanagement employees many of whom fear they may loose their jobs after being used by management to achieve productivity improvements.

(iii) Complaints about fair treatment- Among the practices included in this category are complaints, and grievance procedures. Whilst complaint is a verbal or written dissatisfaction brought to the attention of a manager, grievance is a formal complaint made to an appropriate management representative or to a union official (Torrington et al 2008). Grievance procedure introduces formality to grievance. As Torrington et al (2008) explain, formalization provides a structure within which grievance can be aired without the likelihood that managers would evade the issues. It also eliminates inconsistent ad hoc decision by management while assuring employees that the matter will be heard.

This form of voice goes beyond the domain of how employees' work is organized. It serves to articulate workers anxieties and concerns about management style and practice, either directly to managers or through their representatives (Marchington, 2010). For Marchington (2010), it is the form most commonly associated with voice in the extent that it encapsulate every attempt by employees, either as individuals or as collectives, to force change in objectionable management behaviour rather than quit the organisation (Hirschmann, 1970 in Marchington 2010). 
In effect workers, by means of their voice, are able to fight for improvements in their working lives instead of exiting the organisation. Indeed, Freeman and Medoft (1984, cited in Marchington, 2010) seem convinced that this voice option prevents degeneration in the employment relationship and ensures that unions, on account of their independence from management, provide the best opportunity for workers to exercise their voice.

On the flip side, this form of voice may not be that attractive to employees. Many workers may be disinclined to initiating grievance because of the perception that it may prove to be futile attempt. It has been noted that grievance are rare because only few employees would boldly question their superiors' judgement and many would not want to be tagged as troublemakers, a potent threat to their progress/promotion at work (Torrington et al. 2008; Marchington, 2010). Besides, whilst pluralist managers may see complaints and grievances raised by workers as sources of valuable feedback, more unitarist managers may perceive grievances as challenge to managerial prerogative and would rather such individuals exit the organisation (Marchington, 2010). Hence, Luchak (2003) had observed that generally, to avoid management hostility, employees tend to use more direct voice channels such as complaints and less of the representative voice, which grievance procedure do seem to also fall into.

\section{Indirect Representative Voice}

This refers to voice practices in which employees express their voice through representatives. Practice included here are joint consultation, partnership schemes, work councils, and collective representation epitomized by collective bargaining (Armstrong 2009). However, since both partnership schemes and work councils are not global practices but found in varied forms mostly in European countries (Hollingshead \& Leat, 1995), our interest in the current study is on joint consultation and collective representation.

(i) Joint consultation (JC): a process which provides the means for management to exchange views and information with employee representatives. It deals with matters of mutual interest to both parties which are not the subject of collective bargaining (Armstrong, 2009). It is a two-way communication mechanism wherein management hopes to tap into members knowledge and expertise. In the joint consultative committee management presents issues to employee representatives who in turn comment on and possibly suggest alternatives (Hollingshead \&Leat (1995). Here, managerial prerogative still holds away since management is not bound by the view or suggestions made by employee representatives. Indeed, some employers support JC simply as an alternative to collective bargaining and to discourage trade unionism amongst employees (Hollinshead \& Leat, 1995).

Collective representation: According to Armstrong (2009), this encapsulates the role of trade unions and other employee associations in collective bargaining (CB) and in representing the interests of employees as individuals or as groups respectively. In this context, an apt definition of CB is that by Gospel and Palmer (1993:20) which sees it as 'a process by which trade unions and similar associations representing groups of employees, negotiate with employers or their representatives with the object of reaching collective agreement'. As is evident from this definition, CB, as a process, is collective, representative but not limited to only trade unions, involves negotiation conducted between representatives of employers and employees with the objective of reaching an agreement. Thus, CB clearly fits into the garb of representative voice. It enhances employee involvement in decision making, effectively diluting managerial prerogative.

From the literature reviewed so far there is a little doubt that a variety of voice practices -both direct and indirect - do exist in industry. Also it appears voice schemes depend largely on management support and cooperation for their existence and sustainability. And employees are often not enthused about participation in voice schemes (Hollingshead \& Leat 1995). Besides, research suggests that several voice forms existing together is more reinforcing and more acceptable to workers than any single practice alone (Benson \& Lawler, 2003; Marchington, 2010).Given these, the study explores the following hypotheses:

$\mathrm{Ho}_{1}$ :There is no significant relationship between the existence of direct voice schemes and management's support for them.

$\mathrm{Ho}_{2}$ : There is no significant relationship between the existence of direct voice schemes and employees perception of say over workplace decisions.

\section{Research Method}

The study adopted a cross-sectional survey design. The population of the study comprised all employing organisations in south - south Nigeria. Since it was not possible to access all workers, a non - probability convenience sampling technique was used to access respondents from across five sectors namely, construction, manufacturing, financial services, services/utilities, and oil and gas. The use of convenience sampling is justified in the extent that it is "for the purpose of learning and the sample will provide the information needed" (Perla \& Provost, 2012:71). 
The data collection instrument was a structured questionnaire made up of two sections. The first section sought respondents background information and the second section made up of 32 items, assessed respondents perceptions of the existence and the functionality of any existing voice schemes. Item statements in this section, were drawn from extant literature and their assessment was on a 4 - point Likert - type scale which ranged from strongly agree (4) through to strongly disagree (1). Reliability of the study constructs namely: Direct voice (10 items), management commitment to voice ( 9 items) and employee say (9 items) recorded values above 0.70 , the cronbach's alpha threshold and presented in table 1.

A total of 450 respondents completed the survey instrument out of which 307 were usable. Data analysis was mainly by means of descriptive statistics and the hypotheses were tested using spearman rank order correlation coefficient.

Table 1: Reliability statistics of the study variable

\begin{tabular}{|l|l|l|}
\hline Construct & No. of Items & Cronbach Alpha \\
\hline Direct Voice & 9 & 0.734 \\
\hline Employee Say & 9 & 0.708 \\
\hline Management Support to Voice & 10 & 0.783 \\
\hline
\end{tabular}

\section{Results}

\section{Descriptive Results: Univariate Analysis}

Table 2: Univariate analysis showing means, standard deviations and percentages

\begin{tabular}{|c|c|c|c|c|c|c|c|}
\hline $\begin{array}{l}\mathbf{s} / \\
\mathbf{n}\end{array}$ & Statement & $\begin{array}{cc} & \begin{array}{c}\text { Strongly } \\
\text { agree } \\
\text { F }\end{array} \\
(\%)\end{array}$ & $\begin{array}{l}\text { Agree } \\
(\%)\end{array}$ & $\begin{array}{l}\text { Disagree } \\
\text { F }(\%)\end{array}$ & $\begin{array}{l}\text { Strongly } \\
\text { disagree } \\
\text { F }(\%)\end{array}$ & Mean & SD \\
\hline 1. & $\begin{array}{l}\text { Managers in my organisation encourage employees to have a say in the way } \\
\text { work is organized. }\end{array}$ & $99 \quad(32)$ & $162(53)$ & $44 \quad(14)$ & $02 \quad(0.7)$ & 3.17 & .682 \\
\hline 2. & $\begin{array}{l}\text { In my organisational, different voice systems exist through which } \\
\text { employees express their views and concerns to management. }\end{array}$ & $108 \quad(35)$ & $113 \quad(37)$ & $73 \quad(24)$ & $13 \quad(4)$ & 3.03 & .872 \\
\hline 3. & Employees in my organisation willingly embrace voice practices. & $45 \quad(15)$ & $196(63.8)$ & 57 (18.6) & $9 \quad(3)$ & 2.90 & .664 \\
\hline 4. & I have a say in making decisions which affect my job. & $64 \quad(21)$ & $187 \quad(61)$ & $49 \quad(16)$ & $07 \quad(2)$ & 3.00 & .679 \\
\hline 5. & $\begin{array}{l}\text { Allowing employees contribute ideas/suggestion as to the way work is } \\
\text { organized has encouraged cooperation with management. }\end{array}$ & $54 \quad(17)$ & $193 \quad(63)$ & $52 \quad(17)$ & (3) & 2.95 & .670 \\
\hline 6. & $\begin{array}{l}\text { Allowing workers in my organisation have more say makes their job more } \\
\text { satisfying. }\end{array}$ & $85 \quad(28)$ & $121 \quad(39)$ & $71 \quad(23)$ & $30 \quad(10)$ & 2.85 & .938 \\
\hline 7. & $\begin{array}{l}\text { In my organisation, encouraging employees to have more say leads to } \\
\text { greater work intensity. }\end{array}$ & $91 \quad(30)$ & $(32)$ & $84 \quad(27)$ & $33 \quad(11)$ & 2.81 & .983 \\
\hline 8. & $\begin{array}{l}\text { I like to be informed by management, not take part in making work } \\
\text { decisions. }\end{array}$ & $85 \quad(28)$ & (27) & $123(40)$ & $17 \quad(5)$ & 2.77 & .920 \\
\hline 9. & $\begin{array}{l}\text { In my organisation, involving employee representatives in joint decision } \\
\text { making with management increases employees perception of say. }\end{array}$ & $79 \quad(26)$ & $155 \quad(50)$ & $65 \quad(21)$ & (3) & 2.99 & .758 \\
\hline 10 & I will prefer workers full control of the workplace. & $49 \quad(16)$ & $113 \quad(37)$ & $121(39)$ & $24 \quad(8)$ & 2.61 & .846 \\
\hline 11 & $\begin{array}{l}\text { In my organisation, managers generally lack interest in voice practices } \\
\text { because of their cost implications. }\end{array}$ & $46 \quad(15)$ & $154 \quad(50)$ & $83 \quad(27)$ & $24 \quad(8)$ & 2.72 & .811 \\
\hline $\begin{array}{l}12 \\
\cdot\end{array}$ & $\begin{array}{l}\text { In my organisation, procedure for submission of ideas/suggestions to } \\
\text { management is easy and straight forward. }\end{array}$ & $52 \quad(17)$ & $170 \quad(55)$ & $70 \quad(23)$ & $15 \quad(5)$ & 2.84 & .755 \\
\hline 13 & $\begin{array}{l}\text { In my organisation, employees ideas and suggestions are not ignored by } \\
\text { management. }\end{array}$ & $45 \quad(15)$ & $196 \quad(64)$ & $57 \quad(19)$ & (3) & 2.82 & .882 \\
\hline 14 & $\begin{array}{l}\text { Employees ideas and suggestions found beneficial to the organisation are } \\
\text { rewarded. }\end{array}$ & $52 \quad(17)$ & $125 \quad(41)$ & $78 \quad(25)$ & $52 \quad(17)$ & 2.58 & .962 \\
\hline 15 & $\begin{array}{l}\text { Employees in my organisation fear that improvements } \\
\text { resulting from their suggestions/ideas may lead to job losses. }\end{array}$ & $59 \quad(19)$ & (27) & $106 \quad(35)$ & $60 \quad(19)$ & 2.46 & 1.013 \\
\hline 16 & Management in my organisation use periodic attitude survey of employees. & $48 \quad(16)$ & $146 \quad(48)$ & $84 \quad(27)$ & $29 \quad(9)$ & 2.69 & .846 \\
\hline $\begin{array}{l}17 \\
\cdot\end{array}$ & $\begin{array}{l}\text { In my organisation, attitude surveys serve to gauge employee morale, } \\
\text { commitment, preferences and potential problem areas. }\end{array}$ & $41 \quad(13)$ & $184 \quad(60)$ & $51 \quad(17)$ & $31 \quad(10)$ & 2.77 & .807 \\
\hline 18 & $\begin{array}{l}\text { Problems revealed from attitude surveys are promptly addressed by } \\
\text { management. }\end{array}$ & $64 \quad(21)$ & $136 \quad$ (44) & $57 \quad(19)$ & $50 \quad(16)$ & 2.70 & .978 \\
\hline
\end{tabular}




\begin{tabular}{|c|c|c|c|c|c|c|c|}
\hline 19 & Information from attitude surveys are used to shape management decisions. & $51 \quad(17)$ & $118 \quad(38)$ & $108 \quad(35)$ & $30 \quad(10)$ & 2.62 & .875 \\
\hline 20 & In my organisation, many employees work in task-based teams. & $41 \quad(13)$ & $120 \quad(39)$ & $115 \quad(38)$ & $31 \quad(10)$ & 2.56 & .847 \\
\hline 21 & Work team members are allowed to organize their work. & $32 \quad(10)$ & $147 \quad(48)$ & $119 \quad(39)$ & (3) & 2.66 & .703 \\
\hline 22 & $\begin{array}{l}\text { Work team members are allowed to appoint their leaders } \\
\text { vithout management's interference. }\end{array}$ & $23 \quad(8)$ & $116 \quad(38)$ & $127 \quad(41)$ & $41 \quad(13)$ & 2.39 & .811 \\
\hline 23 & $\begin{array}{l}\text { Management pays adequate attention to suggestions from problem solving } \\
\text { groups. }\end{array}$ & $59 \quad(19)$ & $146 \quad(47)$ & $76 \quad(25)$ & $26 \quad(9)$ & 2.78 & .855 \\
\hline 24 & $\begin{array}{l}\text { Ideas generated by problem solving groups are implemented by } \\
\text { management. }\end{array}$ & $44 \quad(14)$ & $162 \quad(53)$ & $94 \quad(31)$ & (2) & 2.79 & .706 \\
\hline 25 & $\begin{array}{l}\text { Management listens to employee complaints and attends to them } \\
\text { satisfactorily. }\end{array}$ & $57 \quad(18)$ & $135 \quad(44)$ & $103 \quad(34)$ & $12 \quad(4)$ & 2.77 & .792 \\
\hline 26 & $\begin{array}{l}\text { Workers air their views/complaints freely without fear of being victimized } \\
\text { by management. }\end{array}$ & $52 \quad(17)$ & $138 \quad(45)$ & $102(33)$ & $15 \quad(5)$ & 2.74 & .794 \\
\hline 27 & $\begin{array}{l}\text { There is a procedure in my organisation for employees to file their } \\
\text { grievances. }\end{array}$ & $34 \quad(11)$ & $187 \quad(61)$ & $\begin{array}{ll}73 & (24)\end{array}$ & $13 \quad(4)$ & 2.79 & .689 \\
\hline 28 & Employee grievances are speedily resolved. & $30 \quad(10)$ & $123 \quad(40)$ & $127 \quad(41)$ & (9) & 2.51 & .789 \\
\hline 29 & $\begin{array}{l}\text { In my organisation, employees communicate directly with management on } \\
\text { workplace issues. }\end{array}$ & $27 \quad(9)$ & $134 \quad(43)$ & $125 \quad(41)$ & (7) & 2.54 & .750 \\
\hline 30 & $\begin{array}{l}\text { Managers in my organisation prefer to deal with employees directly than } \\
\text { through their representatives. }\end{array}$ & $27 \quad(9)$ & $147 \quad(47)$ & $110 \quad(36)$ & $(8)$ & 2.58 & .756 \\
\hline 31 & $\begin{array}{l}\text { Managers in my organisation welcomes both direct communication with } \\
\text { employees as well as communication with employees through their } \\
\text { representatives. }\end{array}$ & $48 \quad(15)$ & $155 \quad(51)$ & (23) & $35 \quad(11)$ & 2.70 & .867 \\
\hline 32 & $\begin{array}{l}\text { In my organisation, employees like to deal with management only through } \\
\text { their representatives. }\end{array}$ & $66 \quad(21)$ & $113 \quad$ (37) & $113 \quad(37)$ & (5) & 2.75 & 847 \\
\hline 33 & $\begin{array}{l}\text { Employees in my organisation like to communicate with management } \\
\text { directly as well as through their union/representatives. }\end{array}$ & $75 \quad(24)$ & $162 \quad(53)$ & (18) & (4) & 298 & .775 \\
\hline
\end{tabular}

Table 3: Result of the correlations

Correlations

\begin{tabular}{|c|c|c|c|c|c|}
\hline & & & Direct_Voice & $\begin{array}{l}\text { Mgt_Support_ } \\
\text { to_Voice }\end{array}$ & $\begin{array}{c}\text { Employee_Sa } \\
y\end{array}$ \\
\hline \multirow[t]{9}{*}{ Spearman's rho } & \multirow[t]{3}{*}{ Direct_Voice } & Correlation Coefficient & 1.000 & $.692^{\mathrm{nn}}$ & $.725^{\mathrm{kn}}$ \\
\hline & & Sig. (2-tailed) & & .000 & .000 \\
\hline & & N & 307 & 307 & 307 \\
\hline & \multirow[t]{3}{*}{ Mgt_Support_to_Voice } & Correlation Coefficient & $.692^{\mathrm{nn}}$ & 1.000 & $.708^{\mathrm{n}}$ \\
\hline & & Sig. (2-tailed) & .000 & & .000 \\
\hline & & N & 307 & 307 & 307 \\
\hline & \multirow[t]{3}{*}{ Employee_Say } & Correlation Coefficient & $.725^{\mathrm{kn}}$ & $.708^{\mathrm{Nn}}$ & 1.000 \\
\hline & & Sig. (2-tailed) & .000 & .000 & \\
\hline & & N & 307 & 307 & 307 \\
\hline
\end{tabular}

${ }^{* *}$. Correlation is significant at the 0.01 level (2-tailed).

The percentages, means and standard deviations of items are presented in table 2. In view of the 4-point Likert type scale used, the average mean is 2.50. As shown in the table, the mean scores of most of the items are above the average. However, the items with mean scores below average include that which explored whether team members appoint their leaders without management's interference $(X=2.39$; SD 0.011) and that which explored whether employees fear that 
improvements in their organisation, deriving from their suggestions and/or ideas, would lead to job losses ( $\mathrm{X}=2.46$; SD 1.013).

The item exploring whether employee grievances are speedily resolved scored just above average mean (X 2.51). The highest mean score was from the item which assessed whether managers encourage employees to have a say in the way work is organized (X 3.17 SD 0.682) followed by the item that different voice systems exist through which employee express their views and concerns to management (X 3.03; SD 0.872).

\section{Hypotheses Testing}

Hypothesis $1\left(\mathrm{H}_{1}\right)$ proposed that there is no relationship between the existence of direct voice schemes and management's support for them. The result showed that a significant relationship does exist between them (rho = $0.692 ; \mathrm{p}$ - value $<0.05)$. Therefore we reject the null hypothesis.

The result of the second hypothesis $\left(\mathrm{Ho}_{2}\right)$ which proposed that there is no relationship between existence of direct voice schemes and employees' perception of say over workplace decisions showed rho $=0.725 ; p-$ value $<0.05$. Hence we reject the null hypothesis since the results indicate a significant relationship between existence of direct voice schemes and employees perception of say.

\section{Discussion of Findings}

This study set out to explore the existence and dynamics of employee voice in organisations in South-South, Nigeria. With respect to the existence of direct voice schemes, results from the descriptive statistics suggest the existence of a variety of these. The mean of responses as to whether different voice systems exist is (3.03); $72 \%$ of respondents agreed or strongly agreed to their existence. More specifically, existence of easy and straight forward procedure for submission of ideas and suggestions ( $\mathrm{X}=2.84 ; \mathrm{SD}=0.755 ; 72 \%$ agreeing);

Attitude survey $(\mathrm{X}=2 . \overline{69} ; \mathrm{SD}=0.846 ; 64 \%$ agreeing $)$;

Task-based teams $(X=2.56 ; \mathrm{SD}=0.847 ; 52 \%$ agreeing); and

grievance filing $(\mathrm{X}=2 . \overline{79} ; \mathrm{SD}=0.689 ; 72 \%$ agreeing).

Based on these results, suggestion box appears to be the most popular, followed by grievance filing and attitude survey and lastly task-based work teams.

It is notable that task-based teams, a voice scheme that allows a significant autonomy to employees, appear to enjoy the least support from management. Comparatively, suggestion scheme, which potentially is at the discretion of management to use or ignore suggestions, is more embraced.

Therefore, it seems plausible to suggest that the integrity of team autonomy is berated in the organisations studied. Concerning grievance filing, although a high percentage (72\%) of respondents affirm its existence in their organisations, at the same time, a fewer percentage of respondents (50\%) accept that employee grievances are speedily resolved. In the circumstance, it could be surmised that employees would be less inclined to formally initiate grievance filing.

As results also show, management encourages employees to have a say in the way work is organized (X 3.17, SD $0.682 ; 72 \%$ agreed or strongly agreed); they listen to employee complaints and attend to them satisfactorily $(\mathrm{X}=2.77$; $\mathrm{SD}=0.792 ; 62 \%$ agreed or strongly agreeing); workers air their views without fear of victimization $(\mathrm{X}=2.74 ; \mathrm{SD}=$ $0.794 ; 62 \%$ agreeing or strongly agreeing); and management pays adequate attention to suggestions from problem solving groups $(X=2.78$; SD $0.55 ; 66 \%$ agreeing or strongly agreeing).

From these result, it appears safe to conclude that managements are committed to employee voice schemes. This view is also supported by the result from the first hypothesis $\left(\mathrm{Ho}_{1}\right)$ which suggested a relationship between the existence of direct voice schemes and management's support to them. In any event, given that work teams are also relatively unable to appoint their leaders without interference by management, it appears the model of voice that finds support among managers is that which ensures their prerogative is left intact.

Further, respondents perception of having a say recorded a high mean of (x 3.00; 82\% of them agreeing or strongly agreeing). This is also in consonance with the result of hypothesis $2\left(\mathrm{Ho}_{2}\right)$ which suggested a relationship between existence of direct voice schemes and employees perceptions of say in work decisions. But paradoxically, a significant percentage (55\%) also indicated their preference to be simply informed by management, rather than take part in making work decisions. The paradox could be unraveled if one looks to Boxall and Purcell's (2003) gradation of voice which, as stated earlier, runs from little voice wherein information is simply provided employees through giving opportunities to make suggestions; being consulted during decision making and implementation; to having the right to delay a decision, veto management decision or outright co-determination of decision. It appears, having a say, for these respondents, falls along the lower ('little voice') end of Boxall and Purcell's (2003) voice continuum. In fact, this conclusion is consistent with findings in earlier studies (Oladunni, 1998; Nwuche 2010) which found that workers in 
Nigeria were not enthused by any opportunity for managerial decision making, they preferred this done by management. It is note worthy that even in other climes Hollenshead and Leat (1995) had observed that employees are not overly attracted to participate in direct voice schemes. Another notable result relates to the item which explored whether employees like to communicate with management directly as well as through their unions/representatives. This recorded a high mean (X 2.98, SD 0.775) and 77\% of respondents agreed or strongly agreed they liked both direct and indirect communication with management. Similarly, managers welcome both direct communication with employees as well as communication with employees through their representatives $(X=2.70$; SD 0.867). From these, it is presumable that indirect representative voice also exists thus suggesting that dual voice regimes occur in the organisations used for the study. Following from Bryson's (2004) observation that it is most effective to use direct and indirect voice systems in combination, it could perhaps be safe to suggest that employees' perception of say may have actually derived from the combined usage of both direct and indirect voice systems.

\section{Conclusions}

This study attempts to explore the dynamics of employee voice in organistions located in South-South Nigeria. Although the study provided some useful insights, these are not unassociated with important limitations. The foremost limitation relates to the sampling procedure. In spite of the fact that we were able to obtain a sizable number of respondents from different economic sectors, we cannot assume they are representative enough. Therefore, our conclusions should be considered with some caution. On the other hand, sectoral differences in the perception embrace and support for employee voice is a possibility but this was ignored in our analysis and constitutes a limitation. Another limitation stems from the restriction of the study to organisations located within one geo-political zone in Nigeria. This restriction obviously creates further problem for possible generalizability of the results.

The difficulty in generalizing the results notwithstanding, the study does confirm the existence of both direct and indirect representative voice regimes in the organisations and that both managers and employees welcome their existence though they do seem to prefer different voice regimes. More specifically, the study established that employees perceive they have a say in the way their work is organized and managers do show some commitment to voice schemes. However it does highlight the point that the perception of "say" as well as the support for "say" is a function of the meaning each side in the employment relationship ascribes to it. Whilst employees' perception of say seems to be on the lower order end of Boxall and Purcell's 92003) voice continuum, managers support for voice appears to be on voice forms that do not jeopardize managerial prerogative.

\section{Recommendations}

Given the acclaimed positive influence of employee voice on organisational performance we recommend that managers embrace it whole heartedly. They must go beyond merely giving information to employees and creating half-hearted work teams devoid of real autonomy. In view of the apparent preference of employees for non involvement in decision making, managers need to look to encouraging the kind of behaviour modification among employees that would ginger their improved interest in more participatory behaviour. There is need for the active involvement of competent, knowledgeable and interested workers in making important work place decisions. This would enable organisations contend with the swirling events in the ever changing competitive environment. With respect to method, we recommend that future studies should be more extensive to include more geo-political zones and pay more attention to the representativeness of study sample. Besides, further studies should investigate whether and the extent of sectoral differences, if any, with regard to employees' perception and responsiveness to "say" and managers support for the phenomenon.

\section{References}

Ackers P. Marchington M., Dundon, T. \& Wilkinson A. (2006). 'Employee participation in Britain: from collective bargaining and industrial democracy to employee involvement and social partnership: two decades of Manchester/Loughborough research. Decision 33(1), 77-101.

Appelbaum, E., Bailey, T., Berg, P. and Kallenberg, A. (2000). Manufacturing Advantage: Why high performance work systems pay-off. Ithaca, New York: Cornell University Press.

Armstrong, M. (2009). Armstrong's Handbook of Human resource management practice (11th ed). London: Kogan page.

Batt, R. (2004). Who Benefits from Teams: Comparing workers, supervisors or managers. Industrial Relation 43(1), 183-212.

Benson, J. (2000). Employee Voice in union and Non-union Australian Workplaces. British Journal. Of Industrial Relation, 38(3), 453-459. 
Boroff, K. and Lewin, D. (1997). Loyalty, Voice and intent to Exit a union firm: A conceptual and Empirical Analysis. Industrial and labour Relations Review 51(1), 50-63.

Boxall, P. and Purcell, J. (2003). Strategy and Human Resource Management. Palgrave Macmillan: Basing stoke.

Bryson, A. (2004). Managerial Responsiveness to Union and Non-union Worker Voice in Britain. Industrial Relation, 43(1), 213-241.

Child, J. (2015). Organisation. Contemporary principles and Practice (2nd ed). UK: Wiley.

Clegg, S. Kornberger, M. and Pitsis, T. (2011). Managing \& Organisations. An Introduction to Theory \& Practice (3rd ed). London: Sage.

Dundon, T., Wilkinson, A., Marchington, M. and Ackers, P. (2004). The Meanings and Purpose of Employee Voice. International Journal of Human Resource Management, 15(6), 1149-1170.

Emmanuel, A., Yusuf, Francis M., and Isaaa, O. (2017). Effectof employee Voice management and organisational performance in selected deposit money banks in Enugu State, Nigeria. Global Journal of Engineering Science and Research management, 4 (3), $21-23$.

Georgiadis, K. (2006). Why should Employers Bother with Worker Voce?' In Freeman, R. Boxall, P. and Haynes P. (eds.), What Workers Say: Employee voice in Anglo-American World. Ithaca,NY: Cornell University Press.

Handel, M. and Levine, D. (2004). The Effects of New Work Practices on Workers. Industrial Relations 43(1), 1-43.

Hollingshead, G. and Leat, M. (1995). Human resource Management, an international and comparative perspective. London: Pitman publishing.

Hyman, R. (2005). Whose (social) Partnership'. In M. Smart and Martinez-Lucio (eds,), Partnership and Modernisation in Employee Relations. London: Routledge.

Johnstone S. and Ackers P. (2015). Finding a Voice at Work? New perspectives on Employee Relations. Oxford University Press.

Kitur, C., and Rop, S. (2016). Employee boive and its effect on organisational productivity. A case of KPLC Cidoret. Global Journal of interdisplinary Social Sciences, 5(6), 1-6.

Luchak, A. (2003). What kind of voice do Loyal Employees use? . British Journal of Industrial relation, 41(1), 115135.

Marchington M. (2010). Employee Voice Systems. In The Oxford Handbook of Human Resource Management. Oxford University Press.

Marchington M. and Wilkinson J. (2009). Human Resource Management at Work. People management and Development (4th ed). CIPD.

Marchington, M. (1995). Involvement and participation in Human Resource Management, A critical Text. J. storey (ed). London: Routledge.

Marchington, M. and Kynighou, A. (2012). The Dynamics of Employee Involvement and participation during TurbulentTimes . International Journal of Human Resource Management, 23 (16), 3336-3354.

McCabe, D.M. \& Lewin, D. (1992). Employee Voice: A human resource management perspective. California Management Review, 34(3), 112-123.

McCall, J.J. (2001). Employee voice in corporate governance: A defense of strong participation rights. Business Ethics Quarterly. 11(1), 195-213.

Millward, N., Stevens, M., Smart, D. and Hawes, W. (1992). Workplace Industrial Relations in Transition . Hampshire: Dartmouth Publishing.

Nwuche, C.A. (2010). Employee Involvement (EI) at work: Mere Rhetoric? Uyo Journal of Management Sciences 2(1), 133-152.

Oladunni, S. (1998). Issues in corporate and Human Resource Management in the oil industry: A collection of Essays. Publishing Resource Nig. Ltd.

Paauwe, J. and Boselie, P. (2005). Human Resource Management and Performance: what's Next?'. Human Resource Management Journal, 15(4), 68-83.

Perla, R., and Provost, 1. (2012). Judgement sampling: A health care Improvement perspective. Q manage Health care. 21(3), 170-176.

Ramsay, H., Scholarios, D. and Harley, B. (2000). Employees and High-Performance Work System: Testing inside the Black Box. British Journal of Industrial Relation 38(4), 501-31.

Salamon, M. (1992). Industrial Relations. Theory and practice (2nd ed). UK: Prentice Hall.

Torre, E. (2008). Collective voice mechanisms, HRM practices and organizational performance in Italian manufacturing firms. European Management Journal 30(1), 1-13.

Torrington, D., Hall, L. and Taylor, S. (2008). Human Resource management (7ed). England: Prentice Hall.

Wilkinson, A., Godfrey, G. and Marchington, M. (1997). Bouquet, Brickbats and Blinkers: Total Quality Management and Employee Involvement in Practice'. Organiation studies 18(5), 799-819. 